\title{
Integration Strategy of Italian Expatriates in the French Market: A Case History
}

\author{
Cristina Cazorzi Martinez
}

University of Paris-Dauphine PSL DR\&MO Laboratory, France

Copyright $\bigcirc 2018$ by authors, all rights reserved. Authors agree that this article remains permanently open access under the terms of the Creative Commons Attribution License 4.0 International License

\begin{abstract}
This paper analyses the diversity dimensions and strategy put in place by Italian Expatriates in the French market. The Company belongs to the "Third Italy" Industrial District and we observed the transformation of the local culture into the organizational structure. Corporate culture may be the reference framework of Italian Expatriates and shapes their attitude and approaches. The Cultural Framework Theory is mobilized creating universal references and explaining the collective perceptions of foreigner managers steering local teams. Expatriates are analysed as a social group with their own dynamic and learning systems. Few articles wonder about the Italian model of management with specific details of the expatriate's situation. The paper is a case study describing and explaining a first path to construct a general theory. We analyse, in a second step, the relationship with local culture, and its influence on the management style and the way it spreads in other country.
\end{abstract}

Keywords Cross Cultural Management, Corporate Culture, Cultural Frame Theory, Expatriates, Adjustments

\section{Introduction}

After the economic crisis of 2008, a big party of enterprises made important efforts to conquer new markets. In the last five years, for economic reasons, mergers and acquisitions reached a record and overpassed the threshold before the crisis, with emerging new actors and new buyers. More of them are coming from BRICS (Brazil, Russia, India, China and South Africa) and others are the new protagonists of economic development (South Korea, Vietnam and so on).

Expatriates are becoming a very precious resource because of their function as interfaces between headquarters and local markets and the increasing of international connections, mergers and acquisitions, during the globalisation "Era".

Literature explains that the success of $70 \%$ M\&A is spoiled and reduced by indifference versus a human relations problem. The management of human resources covers an important step in the post-merger integration period [1]. The choice of good managers developing local teams and creating a sufficient level of trust, is becoming a real "Survival System" for many corporate companies.

As a practitioner, I consider important every element that can help to clarify strategy to achieve successful performances facing difficulties of a foreign country.

As a researcher, knowing the expatriate's role, as an interface and control system between Headquarters and the market, I' $m$ interested in the tools used in boosting the local team's performance and creating a satisfactory working environment. These may be generalised and applied to different companies and environments.

In this research, we considered Italian expatriates in France as a social group, showing specific dynamics, searching for internal sources to succeed, overpassing the natural border of diversity. Our objective is to understand and explain what kind of resources they use in order to achieve the performance and act as a common strategy.

For the French team we can use a part of literature, but for Italian expatriates there is a massive lack in studies and literature about the phenomenon.

In this exercise we mobilize the References Theory cultural frame of French school [2] in order to relate local culture characteristics to organisational structure and, consequently, to values promoted and present in some attitudes and approaches of expatriate managers.

The Corporate culture may be, in this case, considered like a bridge creating a framework of values and management's approaches spread by expatriates versus local management.

We propose a case study because of the absence of relevant studies. We are conscious of the limitation of this approach but we think it is a correct way to promote further study.

Three principal questions underline our research. 
1. How Italian expatriates manage local teams and what kind of strategy do they use to obtain successful results?

2. Where do they find resources to obtain it?

3. What is the role of Corporate Culture as a frame of reference?

The present paper is articulated in four main parts: the first concerns the theoretical scope and the literature used, the second explains the method applied and why we chose it, third is related to the findings of the field (diversity dimensions and strategy) and the fourth is dedicated to further paths and the limits of the present paper.

\section{Theoretical Background}

The literature used can be divided into three big fields: 1) papers on IHRM, 2) observation around national culture, individual triggering and organization of the companies, and 3) Italian mainstream research.

Human Resources Literature is focalized on individual aspects and personal characteristics more than social group dynamics. The major interest is staffing, selecting and training individual expatriates $[3,4,5,6]$. In so doing, Social Psychology is interested in "predictive signs" in order to choose the correct manager and speculates on characteristics to obtain a successful expatriation $[7,8$, and 9]

In the present context, we observe a group of Italian expatriates, their dynamic approaches to the local market, the way to manage teams and the relationships among each other. We analysed them from 2008 to 2015 and we discovered that they represent a real community, informal, using mother tongue communication, helping each other in overcoming difficulties, avoiding conflict and combining efforts versus local integration.

The Corporate Culture and Values, norms and beliefs create a reference framework influencing expatriates' cognitive perception and the group's dynamic strategy. [10, $11]$.

The cultural influence on management moods is well known in cross cultural literature $[12,13,14,15,16,17,18]$, but we consider their approach too deterministic in the output expected. The "software of mind" may be too near behaviour's elements without triggering individual levels.

For this reason we prefer to mobilize the French school analysis, $[18,19,20,21,22,23,24,25,26]$ based on qualitative research, in order to create a framework where individual preferences can facilitate localization without destroying differences on individual choices. Framework is a dynamic area where interactions create a knowledge influencing cross border characteristics of values and norms $[27,28,29,30,31]$. Our observations are shaded by individual choices, history and personal interactions and encounters, but seem to maintain a logic coherency to explain some common approaches and attitudes in the day by day management.

The reference to Organization Culture [32] and local system, helps us to simplify the frame, tailoring dimensions of local area nearest the individual attitudes.[33]

Expatriates must adjust their belief in order to be able to manage successfully and adapt performances. This effort causes them to wonder not only about the way to act practically, but also the hidden meaning that is behind the behaviour. The act of simply copying from household habits and applying them in a different world, using their "official" authority, is not a proper way and normally it causes claims of inefficiency in the team. [34, 35]

Social Psychology produces many studies on migrants' behaviours and difficulties $[36,37,38,39,40]$. The use of their models may be only partial in expatriates' habits, observing the discrepancies about timing, social role and human capital. We reiterate that from one side the expatriation is a short time period of no more than five years instead of a lifetime for migrants. On the other side, the economic package and hierarchical position influences the expatriates' status and their families' creating a big divide.

Personal choice for expatriates versus local obligations for migrants (war, fear and survival experience) represent the major difference between expatriates' situations and migrant behaviour. On the contrary, the dual acceptation (subjective adjustments and political host country position) $[41,42,43]$ may have different results in both.

The adjustment is affected by different steps and different phases [44] More recent literature shows no linear progression until the last "mastering step" $[45,46,47,48,49]$.

In spite of this, the duality of process dynamics $[50,51,52]$ plays a role in both individual adaptations [53]. The environment plays a mandatory role valorising or refusing the approach of the foreigner.

Few researchers studied strategies used by expatriates on works environments [54] and the relationship with ethnicity or values. More often they argue "Global manager's existence and the relationship with global elite [55,56,57] passing by "Erasmus" student's community or "third kids" generation. $[58,59$, ]

In the Italian economic literature, the District's system and economic area was well studied in the 80s $[60,61]$.

On the contrary, the Italian Management Model, with the exception of general elements in Globe's Research [62] was normally absent in the literature and seems to wake no interests at all.

The absence can be explained with the too recent creation of the management discipline and maybe with the heritage from historical absence (until 1980) of the employed manager (CEO) [63] .

In fact, except Adriano Olivetti $[64,65,66]$ in the '40's, few articles are focused on managing $[67,68,69]$. In the last years some scholars seem to be more interested in it $([70,71,72,73,74,75,76]$ but they are focalized only on cases 
of Public Economy and Health community. Cross cultural elements, dynamic relationships and Italian expatriate's behaviour, on the contrary, are not a purpose of studies [77].

For the absence of Italian studies, we decide to use the case history study for three main reasons: first, the easy access of the sources; second, the way to study in depth details; and third, the relationship from a small localized area and values denoted in organizational Culture.

The Case Study follows the research study explained by literature $[78,79]$

\section{Methodology}

Our research is a longitudinal study during ten years from September 2005 until the end of 2015. From one side, the limits are set from my personal transfer, as an Italian expatriate in France; and from the other side, by the period of the merge with an American Corporation, cancelling the name and the legacy.

We divided the observations in two specific periods: first, (A) from 2005 until end of 2010 and the second (B) from 2011 until the merge. The differences between two periods are the change of relationship between headquarters and market. In period A, headquarters are only focalized on results allowing relative freedom for the rest. In the second period, on the contrary, there is a bureaucratic approach and massive expatriate attrition.

During the analysis we used three kinds of sources: five books of observations, semi-directive interviews, and indirect sources, such as economic budget, forecast or published Balance.

In the observational books, we note all kind of elements: attitudes, approaches, questions and some notes on which the context for the interviews is made.

The most important sources were 32 semi-directive interviews during the period 2008-2015, representing $99 \%$ of Italian expatriates and $40 \%$ of their local team.

In the fig 1 we show the status and the job role of those interviewed. In the first column, we observed the hierarchical position divided in three different groups: decisional, operational and specialist. The first category includes top managers with direct relationship with headquarters and hierarchical fix, executive jobs with decision making. The second category of operational is represented by middle management with a local hierarchical boss maintaining the link with the headquarters, and third group of specialists are managers steering a project or in the transfer of knowledge of best practices with a huge relationship with market and a variable hierarchical position.

The second column shows the national origin and the third refers to the temporal period.

We can observe a structural difference if we compare period A and period B: in the first period, executive jobs are addressed to local Managers, on the contrary, in the second time period, massive expatriates' use cover it. Local employees are present in more operational roles. Blue collars' absence between people interviewed represented one of the limitations of the analysis representation.

\begin{tabular}{|l|l|l|r|}
\hline position & nationalite & période & qty \\
\hline decisionnel & FR & A & - \\
\hline operationnel & FR & A & 4 \\
\hline specialist & FR & A & 2 \\
\hline decisionnel & IT & A & 3 \\
\hline operationnel & IT & A & 1 \\
\hline specialist & IT & A & 1 \\
\hline decisionnel & FR & B & 1 \\
\hline operationnel & FR & B & 6 \\
\hline specialist & FR & B & 0 \\
\hline decisionnel & IT & B & 4 \\
\hline operationnel & IT & B & 5 \\
\hline specialist & IT & B & 1 \\
\hline \hline decisionnel & IT & C & 1 \\
\hline operationnel & IT & C & 1 \\
\hline TOTALE & & & 32 \\
\hline
\end{tabular}

Figure 1. Interviewed grid

All interviews are collected in mother language, allowing people to express freely in implicit ways using metaphors, specific expressions and dialect terms. All interviews were recorded and transcribed verbatim. The analysis was completed by a recursive system to hear interviews and read transcriptions and vice versa.

Qualitative analysis was decided due to some main reasons: first, we wanted to create an interpretative framework for Italian expatriates' moods not represented in literature, second, we wished to compare cognitive perceptions; analysing what they say and what they do; and finally, we searched for an interpretative way. [80] The most complicated objective was to create a cultural framework and analyses patterns searching for a relationship.

In order to analyse each interviews we applied the Ground Theory method [81] considering it most near to our perception and sensitivity [80], to our participant's position, our field proximity and our use of inductive reasoning.

We used the Nvivo system to help us categorize, cover characteristics and observe relationships. Nvivo allowed us to streamline our frame properly.

\section{Field Observations}

\subsection{Structural Environment}

In order to explain properly the roots of local Cultural framework and to compare the elements observed in the interviews, we must give a brief description of the organizational cultural environment of the Company.

Our research is focalized on an Italian MNC, Indesit Company, a manufacturer belonging to the "third Italy's" area, firmly anchored in Central Italy (Marche), far from the infrastructures facilities. Despite this adverse situation, the Company showed an incredible financial growth more than Thirty five times in thirty-five years and in a short time became a major actor of Italian economic growth. Indesit is 
what literature calls the "Third Italy Company"

The third Italy concept $[82,83]$ was created by Italian Sociology school of Turin to describe a specific economic pattern. In the 1970s, a second wave of industrialization began in Italy 100 years after the first, covering completely new geographical areas and becoming in a short time the economic motor of the country. We keep in mind that the first industrial Revolution was localized in the northwest area in the first half of the XVIII century, while the second was in the centre and central west territory with different specific characteristics.

Most of these are hilly or mountainous regions, far from main roads, situated in the middle of nowhere, where an emigration model was predominant in the last centuries. Normally, a town played a central role in the past offering good education skills and technical knowledge to the industrial district. Local politics, because of the local anchorage and social cohesion, became the interfaces between the civil society and the central power, institutionalizing social needs and public relationships.

The success of this Model is related to the strong social cohesion, solid societal values and norms shared, partnership and membership group consciousness' more than usual macroeconomic keys. A strong technical knowledge, individual engagement approach and local political presence, may explain the creation of what literature calls a "country system". On one side inhabitants are proud to be member of a community, sharing a world vision and having certain values and approaches. On the other side they must accept a certain social pressure and control at risk of being marginalized.

The rapid development from a previously agricultural economy to an industrial one, simplifies social segmentation avoiding complex structural hierarchy, preferring a flat organization and "open door approach".

Reactivity and adaptability are considered the most important attitude to invest in the new world answering to the change of the market environment. For this reason the word "flexibility" is a common meaning to explain positive attitude in employees and useful resource in managers.

The most important elements observed, influencing the management system, are: social and economic structure, the dimension of the enterprises, the original family model and the relationship they maintain with the local field.

In the tab 1 we can see in the first column the four elements, in the second, the major values influencing structure system, and in the third, the specific management's aspects.

Despite Hofstede's writings $[84,85,86]$ the authority distance seems to be very few, near to practical operations, showing no divide between the thinking act and the decision. Hierarchical position is not linked to a special social status, but it is managed in a complex relationship.

The economic agricultural tenant farmers influences the family's referential model, reproducing in the Company the same automatisms. The leader is the father, regulating relationships and conflicts between members of family and influencing brother's cohesion and solidarity. The manager inherits the ambiguity of Latin "Pater Familias" with all internal obligations, emotions, attitudes but also the power on life and death for all members of family.

Table 1. Values Grid

\begin{tabular}{|c|c|c|}
\hline Dimensions & Values related & Influence on management \\
\hline $\begin{array}{l}\text { Weak social } \\
\text { structure and } \\
\text { organization }\end{array}$ & $\begin{array}{c}\text { Nearness of the } \\
\text { authority }\end{array}$ & $\begin{array}{c}\text {-Availability } \\
\text {-Primus inter pares } \\
\text {-Open door method } \\
\text {-Horizontal organization } \\
\text {-Weakness of Unions }\end{array}$ \\
\hline $\begin{array}{c}\text { Agricultural area } \\
\text { Tenant farmer } \\
\text { development }\end{array}$ & $\begin{array}{l}\text { Family group } \\
\text { cohesion }\end{array}$ & $\begin{array}{c}\text {-Pater familias as } \\
\text { regulator } \\
\text {-Brothers solidarity } \\
\text {-Work Hard } \\
\text {-Entrepreneurship }\end{array}$ \\
\hline Small dimensions & Easy to manage & $\begin{array}{l}\text {-Resource flex. } \\
\text {-reactivity } \\
\text {-costs' attention }\end{array}$ \\
\hline Loci Relationship & $\begin{array}{c}\text { Social and } \\
\text { political actions }\end{array}$ & $\begin{array}{l}\text {-Personal Relationship } \\
\text {-High context } \\
\text { communication }\end{array}$ \\
\hline
\end{tabular}

As Contingency Theory teaches, the small dimensions of enterprises, let's managing them faster and easier in order to be always available to change directions following the market hazards.

At last the Country System Structure, explained by Bagnasco [87, 88] shows a strong relationship with local environment, cancelling border outside and inside Company. In other words, values of local areas transmigrate in corporate culture tailoring the organization structure and influencing ways to manage team.

Organizational culture seems to be strongly affected by the related dimensions.

Table 2 compares some management attitudes with values of corporate Culture. In Capital are the original words of the corporate chart and values. It shows that local norms tailored the structural system in the company and created a referential frame for management approaches and attitudes of managers. [89,90,91,93]

Table 2. Organizational values and norms

\begin{tabular}{|c|c|}
\hline Local Values & Organizational Norms \\
\hline Availability of the boss & $\begin{array}{c}\text { Primacy of proximity managers } \\
\text { (IN TOUCH) }\end{array}$ \\
\hline Weak hierarchical relationship & $\begin{array}{c}\text { Face to face relationship and } \\
\text { commitment (IN TOUCH) }\end{array}$ \\
\hline Brothers Solidarity & $\begin{array}{c}\text { Personal engagement } \\
\text { (GENUIN) }\end{array}$ \\
\hline Work Hard & Effectiveness (HAMBITIOUS) \\
\hline Reactivity & $\begin{array}{c}\text { Faster action than Prevention } \\
\text { (INNOVATIF) }\end{array}$ \\
\hline Personal Relationship & RESPECTFUL \\
\hline
\end{tabular}




\subsection{Diversity Dimensions}

Despite the geographical nearness and the presumption of similarity of cultural dimensions, our research shows difficulties and hard and complex adjustments between France and Italy. "The French experience is a very hard history, hard and difficult"

The "transalpine cousins", as the French say, may show different dimensions in organizational structure and managing moods, due not to misleading language or individual capability, but stemming from different systems of sense making and references. In this section, we will try to describe these dimensions, give examples and compare to supposed framework values.

During interviews, we observed four critical categories: hierarchical relationship, procedures and processing analysis, change management, and personal relationship in Business and Controlling.

\subsubsection{Hierarchical Relationship}

Individual relationship with authority is an important dimension of structured organization including legitimacy's acceptation and relationship with the team. Both categories are linked together from a logic bond because legitimation's process may support vertical coordination and the team's management.

We observe that expatriates claim to be submitted to frequent exams by local employees in order to check their educational level, personal characteristics and work competencies.

For this reason, some expatriates tell us «... I'm always explaining that a Master 2 in France or in Italy is the same», "They are always demanding what was my University, but anyway in Italy there are not "Grandes Ecoles» they are only in France .... ". "they try to have some references and they think their educational system is the best»

In effect "If you are not worthy to do it, they cannot accept you". The acceptation of Authority is the fruit of a complex mixture between being worthy and having a strong knowledge. The use of this word in business sounds strange to Italians, because other elements are normally considered in a business relationship, such as good capability, creativity and technical competencies.

To be worthy doesn't mean to have only the necessary capabilities or competencies to recover the role, but it is related to the individual characteristics and the role played in the society $[94,95]$

To be worthy is linked to what is noble and what is not ("noble" opposite "vile" in French). The cultural frame divides between lofty and wretched activities.

In doing so, the manager has the responsibility to cover direct collaborators in case of needing help and to pull them up in order to join the excellence, avoiding only being satisfied to being only better.

For this reason, local employees test foreign managers to understand what kind of leader they will deal with.
The pretext used by the team would be the "singularity" and the "presumed complexity" of the French market: «French Market is very difficult» "If you are foreigner you find it difficult to understand the particularity of this special market » and so on... In reality they try to use the same cases for local and foreign leader.

The latter must show his own lofty status, facilitating his legitimacy and covering his job role, which gives a competitive leverage to manage the team and to broker a successful relationship. The legitimisation helps expatriates, dissolving the logic of the well-known attitude of French teams based on conflict

The authority's hard relationship is underlined by the use of military terms.

«Be right in his boots (literally. etre droit dans ses bottes) " or «standing up (literally Rester Debout) ». These are normal ways to be proud of his own job but also to express the will that nobody can influence it or can change his own mind.

On the French side, conflict is a way to take position, maintaining a propitious situation, and obtain more. The "win-win attitude" is not acceptable and considered as a "fake dream", not achievable in the real world, whereas a "domination" attitude is more frequent.

For expatriates coming from a local culture influenced by weak social segmentation and absence of a union, advocating for a flat organization is a very big issue to overcome.

\subsubsection{Procedures and Processing Analysis}

The organizational structure is based on individual relationships, management's proximity and the consideration of superiority of spoken over written procedures.In procedures and processing analysis, the most important categories are individual acceptance of the rule and the consequent individual behaviour, the preference of anticipation in business changes, and planning the consequences more than reactivity and acting.

As we see above, Corporate Culture prefers reaction than a planned consequence, but French employees on the contrary, give a big importance to logic procedures, written down and certified by an internal Auditor. "French people have more method... ..." as told to us by Italian expatriates.

This approach is not only a practical attitude, but a complete conceptual system. Its consistence is in the "Reason and Logic" processes such as "Thrust's objectives in a Harmonic Research."

For this reason the "Best Way" is mandatory as an emanation of "Beauty".

"They [expatriates] don't act always in the best manner...maybe they achieve the point, but not with best behaviour" or "We would like to know the roots and understand consequences of an action before doing it...."

Logic is the essence of "Beauty and cosmic" elements. These last are inferred by the logic Reason construction, 
due to a critical process from the beginning to the end. This flow is created by human reasoning and finds its "perfection" in the logical framework inside. So, procedures cannot be overpassed easily or modified simply because they are the fruit of human logics and reasons. Procedures must to be obeyed.

In this uniform and orderly world, individual position in the organizational structure must to be clear with confirmed, fixed tasks and job descriptions. This approach contrasts with the idea of individual engagement of expatriates, working hard "out of the box", as signs of emotional attachment to the Company and responsibility versus his own job.

"[They are] beware of workloads, they protect their own scope» or "they have a big difficulty to overpass their proper tasks and their job title» told an Italian manager.

Locals need to live in a "cosmos", logic and reasoning area, where the reactions are considered noises. They are used to plan and prevent instead of reacting fast: they try to know issues in advance and facts before they arise.

On the contrary, Italian managers know very well that they act like a fire brigade, but they master reactivity and fast solutions

"We are used to working always in emergency than in prevention.... we are always blocking the fire instead of preventing it».

This different approach to normal things can cause a clash between the two groups: one thinking that the team is not reacting quickly, and local employees arguing that Italian managers are always acting without knowledge and rational logic approaches.

\subsubsection{Change Management}

The adaptability of the hazardous events belongs directly to the DNA of the third Italy enterprise and is considered a competitive leverage, to arrive first and maintain strong reflexes. For this reason, Indesit always maintained small dimensions compared to the biggest MNCs. The founder is used to saying "my Pocket MNC" to show the quick and easy way to move in the market world's troubles.

In the interviews, all Italian Expatriates consider adaptability the most important characteristic of a collaborator and a Team. This approach is attested by the Company's attitude changing quickly and frequently organisations and organograms. "This is a natural boiling water... Change is a good health sign for this Company".

Changing fast and often has two objectives: first, master the innovation as a continuous progress and second, attend to excellence. The acceptance by French employees is based on the perception of taking part in an important Project and with the increasing of Benefits. Their natural fear for universal discomfort and not planned change is wiped out by the perception of belonging to the spearhead of the Company.

The innovation is easy because we are not obliged "to turn around all procedures... we are fast" Open availability is a powerful instrument to create and recreate and adapt the organisational structure to the change. The company works with a matrix organisation, not following all the hierarchical steps, but privileging the functional relationship and horizontal and transversal collaboration.

It seems that, barring exceptions, the normal attitude of local employees who prefer a planned and routine atmosphere, can be overpassed by the consciousness to be part of big project and to be proud to be at the tip of a new system.

"The problem \{for local employees\} is loving to be a little narrow-minded" but "we must adapt ourselves .... [Because] we must take part to the Company building project"

Adding perception to be part in more big Design and a particular system of management, expatriates try to adapt teams not normally prone to a change framework, and help them accept open environment.

"We trust in people ... we let some free margins to act ...we appreciate a lot problem solving approaches..."

A special management way, in period A, aiming for autonomy more than bureaucratic control, helps in acceptance of frequent changes.

"In Indesit we like creative people that always have a solution. We trust in their acts and allow their own autonomy...."

\subsubsection{Personal Relationship during Business Life and Control Elements.}

The face to face relationship has a big importance in structure of the Company's organization. For this reason, the operational managers are the most important relay to the executive board. Without him, steering the company seems to be impossible and the change to be in the same "mood" (managers and employees) may facilitate the work.

In the interviews, we noticed a big cross cultural issue considering the formal and informal behaviour, expression of emotion, and private life consequences.

For the first point, Italian managers love transparent and direct relationships and consider showing interest to every individual people in the office a waste of time. French employees, on the contrary, give a lot of interest to this daily ritual, considering this an act to structure the acknowledgement of individual positions.

A French employee told us: "They don't say Good Morning, they don't consider us....They are in a conquered ground. They take us for pinots" For this reason, a French director told an Italian colleague: «It's necessary you force yourself to take time going around all offices. It's really important if not they say you are arrogant and you will be 
never integrated in the group"

In a similar way, every control is considered as a lack of regards for one's own competencies in the job. For expatriates to check all details and demonstrate a correct knowledge of activity is a way to be sure all decisions are put in place, not operating from a different logic than proximity to manage the team.

On the other side French employees don't like to be controlled, because they prefer to follow rules pertaining to the job area and individual competencies. This is a Trustworthy approach on both sides: autonomy for locals and legitimacy for foreigners.

For this last reason, the second period's (B) tough central bureaucratic control, did not yield predictable results, creating a fighting atmosphere and infantilizing local managers.

In table 3 we summarize a brief vision of the most evident of Diversity's dimensions. It looks like an impossible or risky gamble, but as we explain later, expatriates try to overcome them using some tools and instruments they find.

Expatriates and local employees can meet themselves and find a successful way to work together.

Table 3. Diversity Dimensions 'Synthesis

\begin{tabular}{|c|c|c|}
\hline Dimensions & Italian Expatriates & French local Team \\
\hline Vertical Coord. & Proximity MNG & Worthy Theory \\
\hline Procedures & Reactivity & Prevention \\
\hline Formal/informal & General approach & Individual approach \\
\hline Control & Bureaucratic & Autonomy \\
\hline
\end{tabular}

\subsection{Strategy of the Expatriates}

The Four categories observed are a heavy daily burden, causing clashes, internal war and many difficulties: the famous French conflict against authority came back shining in its own aura.

During the interviews, we observed a specific expatriates' strategy to minimize the risk, obtain the best and have a satisfactory relationship with the group.

The system seems to be composed of three elements: the effort to integrate the group, the existence of a certain complementarity, and the force of mediation.

Integration, for the Italians managers, may be essential to maintain the leverage and the power's shifters of the Team.

In this model, two components are instrumental to strengthening the organizational building: playing on the subsidiary's attributes and the determination to negotiate.

Figure 2 shows the integration as a central element in the expatriate's strategy. On the left side, the facilitators; and on the right, the consequences of accomplishing integration.

We consider facilitator elements to be: speaking the local language, humble attitude and consequently an open mind set.

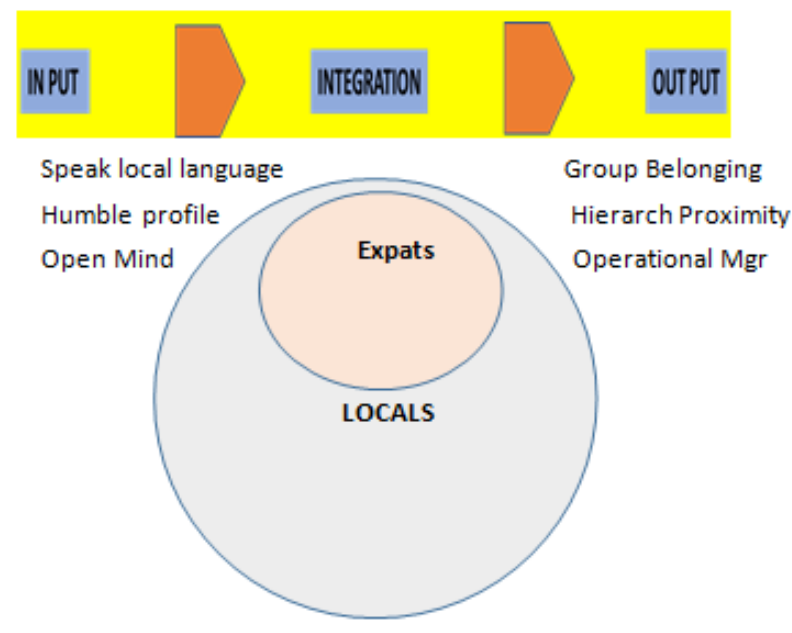

Figure 2. Model of integration

To speak the local language or to learn, it is mandatory in order to avoid use of a "lingua Franca" which cannot explain meanings and implicit codes in human relations. The face to face relationship, proximity of the field and team trust are considered major points in the connection to the local market.

Low profile means not be closed in a narrow approach, not giving lessons, and showing an open attitude that can influence the approach.

Flat hierarchical structure and proximity management, shares power and helps expatriates in their efforts to be considered as one of the group and not a foreigner.

Integration has an improper meaning, because it substitutes the word most often used: adjustments [96, 97].

We decide to use it, because all interviews underline an inflation of integration terms, as a strong perception by Italian managers.

"The expatriate's position is more peculiar because expatriate needs to gain the group's trust in order to insert himself in a consolidated one. He is the exception and the group's relationship is the rule.»

We observe that they need to be adopted by the group; the success of the mission is strictly related to it and it seems that no further step would be possible without this previous status.

"If you are not considered in the group you can not only make a mistake, but it would be really difficult to manage them» «First thing is to be on their side»

The action to be integrated is considered a facilitator to understanding the team and to perform correctly. We must act and handle from the inside as a Trojan horse, spreading Corporate culture, transferring knowledge and organizational moods.

Powerful social cohesion is the heart of the mission; in achieving it, the manager is available, flexible and ready to adapt to new contexts. We must understand the tacit rules of 
groups in order to adjust, interpret and transform them. You must adapt yourself and not vice versa because the group was created before you and you have to make efforts to integrate.

An Italian Director tried to explain this approach with the «emigration past» that obliges us to «maintain low profiles» in order to neutralize potential conflicts.

"The integration problem is a typical Italian trouble, I don't mind that my English colleagues have the same if they will go in Dubai or France, except for individual appreciating level»... "This issue has its origin in the presumed «cultural 》 disadvantage when we go to richer countries or the area of Northern Europe. "

For this reason, expatriates show special needs to learn or to speak local languages to communicate properly and integrate into the group. Communication using the local language, is considered a main point to crossing the barriers and achieving the Team.

"For me I thought I would speed up the language knowledge. Because I must do the first step"

"If I compare myself to English people, I'm conscious of the language disadvantage.... This is a communication issue.... for this reason, we make a lot efforts on hearing and understanding others' speaking...»

If we observe the two related elements of integration and we compare them to the reference of local culture and its influences on management, we can find some common points in flat hierarchical organization, the relationship regulation system and importance of social cohesion.

The language knowledge is a facilitator to create interpersonal relationships and establish, manage and boost the team. It can be essential in order to coordinate people and understand not only what they say but how, when and why [97, 98, 99, and 100].

The emigration history, in the underlying values of the original area of the Company's birth, boosts the corporate culture, not imposing, but proposing value policy.

Legitimacy is a social construction that can fall down without the proximity of power, only one direction giving sense to the authority structure.

Expatriates know only this way to succeed and they try to apply it in the foreign country.

For this reason, they don't like French conflict and they try to neutralize it, showing more flexible choices, adaptability and nearness to the team issues.

In figure 3 we can observe the components that build integration and the consequences of their application.

As we explained before, complementarity facilitates the construction of the group's collaboration, reinforcing its competitive leverage by the presence of diversity and obtain the best performance [101, 102]. If the integration is the organizational tool to achieve membership and legitimate authority, complementarity is the pillar you can use to build the collaboration.

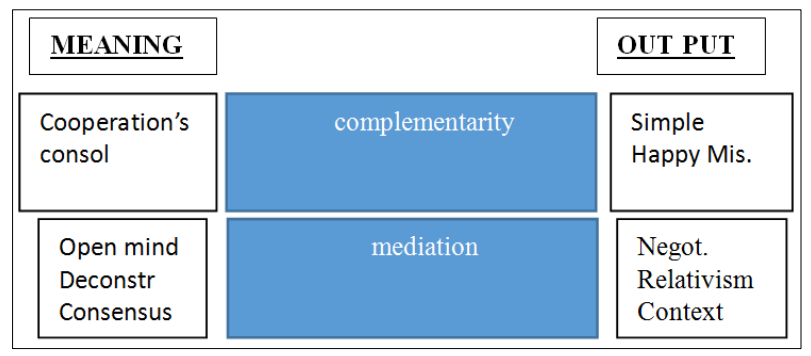

Figure 3. Tools to use

A Simple complementarity between Italian and French employees adds flexibility (Italian side) to a more structured and complex approach (French employees). Managers and employees use procedures if they are useful and globally complain, but decide to evade requirement, when they must speed up or if they turn around. French employees, endorsed by their managers, have less fear in doing something that skirts established processes but add reactivity in problem solving. Problem solving and decision making have to be a normal habit and sharing power for all members of the group avoiding «passing all the hierarchical step to have a decision».

"I'm convinced after a long period with an Italian French team, that they have complementary habits. The accelerating way may find a rapid solution overpassing procedural steps. It is useful in a hurry, but when a correct plan is needed to forecast futures challenges, we must use the French team. Not vice versa, because it would be a mess. The Italian team developed a capability to untangle that the French have not"

Combining the two approaches creates a competitive leverage achieving success easily and clarifying roles and objectives. This can be an «Atout» in multicultural groups $[103,104,105]$

«For this reason, I consider mixed composition of the Teams in a very positive way. From the French side the faith in the logic method lets building the organization with solid roots, from the Italian we can derogate sometimes in order to be nearer the market changes»

We can observe also some "happy misunderstandings". We consider it such, when a structured concept combines two different meanings in the two different perception's networks. In this case, a controversial concept is referenced in a positive way, transforming a mistake into a good tool.

This phenomenon is known in cross culture management as a positive transformation of concept from a prior negative sense [106,107,108,109,110].

For example, the term "proactivity" means a mixed of flexibility and adaptability. In all interviews, this is a major attribute Italian expatriate's search for in a collaborator. 
Among French Teams, on the contrary, the best Leader is someone that allows them freedom to follow their own job logic and rules, boosting specific competencies. The control is addressed on results but not how they were achieved. This is "the mantra" of employee's autonomous field. In the French universe, conflict is overcome only by accepting freedom and autonomy of the collaborator, who creates a logic coherence in authority and accepts vertical coordination and hierarchical schemes $[110,112,113,114,11$ $5,116]$.

«My favourable Leader is someone who lets me free to do my own job, because he is not more expert than me to do $i t$ » or «I would like someone who is able to give the scope, not doing all details of the work»

Flexibility is, on the contrary, considered by the French world as accepting everything until doing tasks with no specific knowledge. It's a way to succumb in the face of hierarchical orders.

Exactly the opposite to "standing up" that we discussed above, the fusion of the two opposite concepts, in a unique positive acceptation, created by the term "Proactivity", which means to find complex solutions, not following usual paths, grazing the excellence. In this way "the flexibility concept" can be substituted by a competency's frame and logic construction.

"We don't write more, we pretend that someone has, on his own, a part of entrepreneurship and has responsibility",

Individual responsibility has a strong value in order to find a solution and propose a way. In this case, collaborator engagement is not represented only to cover a task, but to exceed the simple execution.

"We trust people, we leave a big margin of autonomy. We appreciate them having solution catching delays that we cannot avoid.... We love proactive people"

Following complementarity, some words about mediation.

This specific attitude of Italian expatriates is inspired by the importance of the context, a certain relativism on solutions and adaptation's behaviour. Italian expatriates try to, create a new limited consensus managing unfriendly teams.

Mediation has different connotations in both countries. Larousse dictionary interprets the terms as "a specific intervention made by a third party in order to pacify a conflict between two different parties". In Italian we don't need a third party or a professional intervention, but mediation is a common way to act and take decisions. [117].

A compromise is always used in order to join the «median» point: this is the best position ("Sectio Aurea" of Leon Battista Alberti) for the best decision. Mar Lazar asserts that always maintaining his own position is considered a dull point; on the contrary. Always searching for a middle way in order to find a solution, is considered a «win -win «approach».

\section{"I cannot say do this or do that, but I must negotiate every act»}

The humble profile and the integration process achieved before influences the openness and the capability to negotiate one's own position.

As expatriates said, «if you communicate and you discuss everything, at the end it works.... ».

"The approach is always to demonstrate one by one all decisions taken, and statements chosen with our unconcerned habit"

Managers go on negotiating positions, decisions and actions because they hold few stereotypes and the manner of their steering is completely "ready-made" $[118$, $119,120]$.

In conclusion, we can confirm that humble attitudes and mediation processes are the most important tools expatriates use in the French market; negotiating all decisions is the best way to deconstruct opposition and conflicts of the local team. This approach is enabled by the efforts in integration and speaking the local language.

\section{Conclusions, Limits and Extensions}

This paper is only the beginning of a more extensive discussion and future research. Nevertheless, we think that some points may be observed and discussed.

On the first level, we have answered the three main questions. We observed first the elements of the strategy used by expatriates to manage and collaborate with local teams. Integration, complementarity and negotiation approaches are the main tools to build collaboration and boost performance. The original local Company's culture seems to influence organizational structure creating the relationship between outside the Company and inside. This frame creates an effect on the expatriates' approaches and management's attitudes.

The geographical proximity of the two countries, what literature calls "cultural distance", demonstrates the difficulty to grasp this concept. France and Italy in the Hofstede grid seem to be very similar, but there are always dynamics at play, running by comparison and not static.

The second point is the managing the relevance of cultural attributes: in reality what seems very little, can be bigger and more difficult to overcome. For Italian managers, there is a precise difficulty in mobilizing the local group.

For the third point, we think we have given a point that begins to explain how expatriates deal with diversity dimensions. They use these elements to overcome obstacles, minimize conflict and improve the environment

The framework of reference is only beginning to be 
scratched: in effect, it will be a long time before a complete drawing is revealed.

The case study doesn't promote a generalization of rules and effects. Using a local culture, we avoid simplistic generalizations and deterministic conclusions, but we are also aware of the limits of this approach.

Many questions are ready for further paths: can the strategy of Indesit expatriates be indicated as common to other Companies in the same District? In other words, can we extend some points of the local culture to the whole District or is what we observe strictly limited to the Indesit Company?

What happens when Italian expatriates go to Southern Countries? Do we argue that the same approach is used or can we look for a change? In other words what is happening to the humble habit when economic domination may interfere?

All the questions refer to the absence of a cultural framework in Italian management studies and we are conscious that only a first step was done with this paper, but many other points must be to clarify defining adjustments of expatriates.

\section{REFERENCES}

[1] Epstein MJ. The determinants and evaluation of merger success. Business Horizons. 2005 Jan 1;48 (1):37-46.

[2] D'Iribarne P. Uun management moderne dans une culture traditionnelle. Les enseignements d'une success-story mexicaine... Gérer et Comprendre, (65), 5-16.

[3] Au KY, Fukuda J. Boundary spanning behaviors of expatriates. Journal of World Business. 2002 Dec 1; 37 (4):285-96.

[4] Aycan Z. Acculturation of expatriate managers: A process model of adjustment and performance. Elsevier Science/JAI Press; 1997.

[5] Black JS, Mendenhall M. The U-curve adjustment hypothesis revisited: A review and theoretical framework. Journal of International Business Studies. 1991 Jun 1; 22(2):225-47.

[6] Mendenhall ME, Dunbar E, Oddou GR. Expatriate selection, training and career - pathing: a review and critique. Human Resource Management. 1987 Sep; 26(3):331-45.

[7] Caligiuri PM. The big five personality characteristics as predictors of expatriate's desire to terminate the assignment and supervisor - rated performance. Personnel psychology. 2000 Mar; 53 (1):67-88

[8] Caligiuri P, Santo VD. Global competence: what is it, and can it be developed through global assignments? Human Resource Planning. 2001 Jul 1; 24(3).

[9] Caligiuri P, Phillips J, Lazarova M, Tarique I, Burgi P. The theory of met expectations applied to expatriate adjustment: The role of cross-cultural training. International Journal of
Human Resource Management. 2001 Jan 1;12(3):357-72.

[10] Schaaper J. Contrôle multidimensionnel d'une filiale à l'étranger: construction d'un modèle causal à partir du cas des multinationales européennes et japonaises en Chine. Finance Contrôle Stratégie. 2005; 8 (1):159-90

[11] Schein EH. Organizational culture. American Psychological Association; 1990 Feb.

[12] Hofstede G. Culture's consequences: Comparing values, behaviors, institutions and organizations across nations. Sage publications; 2003 Feb 27.

[13] Hampden-Turner C, Trompenaars F. Au-delà du choc des cultures. Paris: Editions d' Organisation. 2004.

[14] Hofstede G. Culture's consequences: International differences in work-related values. Sage; 1984.LONDON.

[15] Hofstede GH. GJ and Minkov, M. (2010) Cultures and Organizations: Software for the Mind, Revised and expanded.

[16] Hofstede GJ, Pedersen P. Exploring culture: Exercises, stories and synthetic cultures. Nicholas Brealey ; 2002 Sep 24.

[17] Trompenaars F, Hampden-Turner C. Riding the wave of culture. London: Breatley. 1993.

[18] Hampden-Turner CM, Trompenaars F. Building cross-cultural competence: How to create wealth from conflicting values. Yale University Press; 2008 Oct 1.

[19] Chevrier S. Gestion des équipes multiculturelles. E. Davel, JP. 2008.

[20] Chevrier S. Is national culture still relevant to management in a global context? The case of Switzerland. International journal of cross cultural management. 2009 Aug; 9(2):169-83

[21] Chevrier S. Pas de coopération internationale sans prise en compte des cultures. InAnnales des Mines-Gérer et comprendre 2012 (No. 1, pp. 95-97). ESKA.

[22] Chevrier S. Gérer autrement. La Revue des Sciences de gestion. 2012(1):13-5.

[23] d'Iribarne P. La logique de l'honneur. Gestion des entreprises et traditions nationales. Le Seuil; 2015 Jul 25.

[24] d'Iribarne P. The usefulness of an ethnographic approach to the international comparison of organizations. International Studies of Management \& Organization. 1996 Dec 1;26(4):30-47.

[25] d'Iribarne P. Penser la diversité du monde. Le Seuil; 2014 Nov 25.

[26] Segal JP. Les mystères du changement à la française. Le journal de l'école de Paris du management. 2010(3):8-13.

[27] Segal JP. Efficaces, ensemble. Un défi français: Un défi français. Le Seuil; 2014 Aug 27.

[28] Dupuis JP. Intégration des immigrants et conquête des marchés internationaux: le difficile apprentissage des différences culturelles. Sociologie de l'économie, du travail et de l'entreprise. Montréal: Gaëtan Morin. 1997:193-243. 
[29] Dupuy, JP. Anthropologie, culture et organisation-Vers un modèle constructiviste. In L'individu dans l'organisation. Les Dimensions oubliées (Les presses de l'Universite de Laval, pp. 533-552). Monreal: Editions ESKA. 2000

[30] Dupuis JP. À la recherche de ce qui dure au sein des sociétés. Management international. 2009 Jul 1;13 (4):129-33.

[31] Dupuy, J. P. L'analyse interculturelle en gestion: décloisonner les approches classiques. In Dupuis JP, Davel E, Chanlat JF. Gestion en contexte interculturel: approches, problématiques, pratiques et plongées. Paris Dauphine University; 2007.

[32] Schein Edgar H. Organizational culture and leadership. Jossey-Bass, San Francisco Google Scholar. 1992.

[33] Dupuis JP. À la recherche de ce qui dure au sein des sociétés. Management international. 2009 Jul 1;13 (4):129-33.

[34] Berry JW. Immigration, acculturation, and adaptation. Applied psychology. 1997 Jan; 46(1):5-34.

[35] Berry JW. Acculturation: Living successfully in two cultures. International journal of intercultural relations. 2005 Nov 1;29(6):697-712.

[36] Camilleri C, Malewska-Peyre H. Socialization and identity strategies. Handbook of cross-cultural psychology. 1997;2:41-67.

[37] Camilleri C, Vinsonneau G. Psychologie et culture: concepts et méthodes. A. Colin/[VUEF]; 1996.

[38] Dervin F. Developing strategic competence in liquid times. Europa Büro des Stadtschulrats für

[39] Dervin F. The Erasmus experience: halcyon days of hypermodernity. Retrieved June. 2007;25:2014..

[40] Vinsonneau G. Inégalités sociales et procédés identitaires. A. Colin; 1999.

[41] Berry DP, Bell MP. 'Expatriates': gender, race and class distinctions in international management. Gender, Work \& Organization. 2012 Jan;19(1):10-28.

[42] Berry JW. Immigration, acculturation, and adaptation. Applied psychology. 1997 Jan; 46(1):5-34

[43] Berry JW. Acculturation: Living successfully in two cultures. International journal of intercultural relations. 2005 Nov 1;29(6):697-712.

[44] Oberg K. Cultural shock: Adjustment to new cultural environments. Practical anthropology. 1960 Jul;7(4):177-82

[45] Black JS, Mendenhall M. The U-curve adjustment hypothesis revisited: A review and theoretical framework. Journal of International Business Studies. 1991 Jun 1;22(2):225-47.

[46] Black JS, Mendenhall M, Oddou G. Toward a comprehensive model of international adjustment: An integration of multiple theoretical perspectives. Academy of management review. 1991 Apr 1;16(2):291-317.

[47] Mendenhall ME, Dunbar E, Oddou GR. Expatriate selection, training and career - pathing: a review and critique. Human Resource Management. 1987 Sep;26(3):331-45.

[48] Downes M, Thomas AS. Knowledge transfer through expatriation: The U-curve approach to overseas staffing.
Journal of Managerial Issues. 2000 Jul 1:131-49.

[49] Gullahorn JT, Gullahorn JE. An extension of the u - curve hypothesis1. Journal of social issues. 1963 Jul 1;19(3):33-47.

[50] Berry JW. Immigration, acculturation, and adaptation. Applied psychology. 1997 Jan; 46(1):5-34

[51] Berry JW. Acculturation: Living successfully in two cultures. International journal of intercultural relations. 2005 Nov 1;29(6):697-712.

[52] Berry DP, Bell MP. 'Expatriates': gender, race and class distinctions in international management. Gender, Work \& Organization. 2012 Jan;19(1):10-28.

[53] Dupuy, J. P. L'analyse interculturelle en gestion: décloisonner les approches classiques. In Dupuis JP, Davel E, Chanlat JF. Gestion en contexte interculturel: approches, problématiques, pratiques et plongées. Paris Dauphine University; 2007.

[54] Chenou JM. Is Internet governance a democratic process? Multistakeholderism and transnational elites. In ECPR general conference 2011 Aug (pp. 25-27).

[55] Bell-Villada GH, Orr EN, editors. Writing out of limbo: International childhoods, global nomads and third culture kids. Cambridge Scholars Publishing; 2011 Sep 22.

[56] Erez M, Lisak A, Harush R, Glikson E, Nouri R, Shokef E. Going global: Developing management students' cultural intelligence and global identity in culturally diverse virtual teams. Academy of Management Learning \& Education. 2013 Sep;12(3):330-55.

[57] Erez, M., \& Gati, E. (2004). A Dynamic, Multi-Level Model of Culture: From the Micro Level of the Individual to the Macro Level of a Global Culture. APPLIED PSYCHOLOGY: AN INTERNATIONAL REVIEW, 53(4), 583-598.

[58] Bell-Villada GH, Orr EN, editors. Writing out of limbo: International childhoods, global nomads and third culture kids. Cambridge Scholars Publishing; 2011 Sep 22.

[59] Pollock DC, Van Reken RE. Third Culture Kids: Growing Up Among Worlds, Revised. Edition Paperback. 2009.

[60] Bagnasco A, Sabel CF, Brusco S. PME et développement économique en Europe. La Découverte; 1994.

[61] PIORE M, SABEL C. The Second Industrial Divide: Possibilities for Prosperity. New York: Basic.

[62] House RJ, Hanges PJ, Javidan M, Dorfman PW, Gupta V, editors. Culture, leadership, and organizations: The GLOBE study of 62 societies. Sage publications; 2004 Apr 29.

[63] Sapelli G. Gli" organizzatori della produzione" tra struttura d'impresa e modelli culturali. Einaudi; 1981.

[64] Bricco P. Olivetti, prima e dopo Adriano: industria cultura estetica. L'ancora del Mediterraneo; 2005.

[65] Crucini C. Italian Pioneers in Management" Thoughts and Actions": the History of Silvano Del Lungo in Human Resources Management.

[66] Crucini C, Kipping M. Management consultancies as global change agents? Evidence from Italy. Journal of Organizational Change Management. 2001 Dec $1 ; 14(6): 570-89$. 
[67] Masino G. Culture and management in Italy: Tradition, modernization, new challenges. Davel E., JP Dupuis and JF Chanlat, Gestion en contexte interculturel: approches, problé matiques, pratiques et plongées, Presse de l'Université Laval et Télé-université (UQAM), Québec. 2008.

[68] Albano V, Barbini FM, Berdicchia D, Ferri P, Maggi B, Masino G, Salento A. Storie di imprese.

[69] Associati GC. Management Made in Italy. Il modello italiano delle imprese di successo. Milano: Il Sole-24 Ore Libri. 1996.

[70] Giampaoli D, Ciambotti M, Bontis N. Knowledge management, problem solving and performance in top Italian firms. Journal of Knowledge Management. $2017 \mathrm{Apr}$ 3;21(2):355-75.

[71] Hougaz L. Entrepreneurs in Family Business Dynasties. Springer International Publishing: Imprint: Springer,; 2015 Feb 23.

[72] Liker JK, Attolico L. Toyota Way: I 14 principi per la rinascita del sistema industriale italiano-con 14 casi di studio italiani. HOEPLI EDITORE; 2014 Apr 28.

[73] Occorsio E. Reti: quali regole?: la questione-base dello sviluppo italiano. Dalai editore; 2007.

[74] Salomone R. Integrated management systems: experiences in Italian organizations. Journal of cleaner production. 2008 Nov $1 ; 16(16): 1786-806$.

[75] Vagnoni E. Le sfide manageriali delle farmacie: un'analisi del contesto italiano. F. Angeli; 2013.

[76] Kubra Canhilal S, Borgonovi E, Vera E. exploring the values in the Italian public sector using the tri-axial model. Cross Cultural Management. 2013 Oct 14; 20(4):544-58.

[77] Serio L, editor. The Italian Model of Management: A Selection of Case Studies. Routledge; 2018 Apr 27.

[78] Eisenhardt KM. Building theories from case study research. Academy of management review. 1989 Oct 1; 14(4):532-50.

[79] Yin RK. Case study research: Design and methods (applied social research methods). London and Singapore: Sage. 2009.

[80] Corbin J, Strauss A, Strauss AL. Basics of qualitative research. Sage; 2014 Dec 5.

[81] Glaser BG, Strauss AL. The discovery of grounded theory: strategies for qualitative theory. New Brunswick: Aldine Transaction. 1967.

[82] Glaser B. Theoretical sensitivity. Advances in the methodology of grounded theory. 1978.

[83] Bagnasco A. Tre Italie: La Problematica Territoriale dello Sviluppo Italiano (Il Mulino, Bologna)

[84] Bagnasco A, Trigilla C, Berthet T, Marenco C. La construction sociale du marché(le défi de la troisième Italie). Collection sciences sociales. 1993.

[85] Hofstede G. Culture's consequences: Comparing values, behaviors, institutions and organizations across nations. Sage publications; 2003 Feb 27.

[86] Hofstede G. Culture's consequences: International differences in work-related values. Sage; 1984.LONDON.

[87] Hofstede GH. GJ and Minkov, M. (2010) Cultures and Organizations: Software for the Mind, Revised and expanded.

[88] Bagnasco A. Tre Italie: La Problematica Territoriale dello Sviluppo Italiano (Il Mulino, Bologna)

[89] Bagnasco A, Trigilla C, Berthet T, Marenco C. La construction sociale du marché(le défi de la troisième Italie). Collection sciences sociales. 1993.

[90] ODOR HO. Organisational Culture and Dynamics. Global Journal of Management and Business Research. 2018 Jan 25.

[91] Handy CB. Understanding Organisations 4th Edition London Penguin.

[92] Alvesson M. Understanding organizational culture. Sage; 2012 Nov 16.

[93] Cameron K, Quinn RE. Organizational culture assessment instrument.

[94] d'Iribarne P. La logique de l'honneur. Gestion des entreprises et traditions nationales. Le Seuil; 2015 Jul 25.

[95] de Secondat Montesquieu CL. De l'esprit des lois. Garnier frères; 1869.

[96] Berry JW. Acculturation: Living successfully in two cultures. International journal of intercultural relations. 2005 Nov 1;29(6):697-712.

[97] Berry DP, Bell MP. 'Expatriates': gender, race and class distinctions in international management. Gender, Work \& Organization. 2012 Jan;19(1):10-28.

[98] Chanlat JF. L'individu dans l'organisation: les dimensions oubliées. Presses Université Laval; 1990.

[99] Chanlat JF. Langue et pensée dans le champ de la recherche en gestion: constats et enjeux et atouts de la langue française. InAnnales des Mines-Gérer et comprendre 2014 (No. 1, pp. 4-17). ESKA.

[100] Fredriksson R, Barner-Rasmussen W, Piekkari R. The multinational corporation as a multilingual organization: The notion of a common corporate language. Corporate Communications: An International Journal. 2006 Oct $1 ; 11(4): 406-23$.

[101] Feely AJ, Harzing AW. Language management in multinational companies. Cross Cultural Management: An International Journal. 2003 Jun 1;10(2):37-52.

[102] Chevrier S. Cross-cultural management in multinational project groups. Journal of world business. 2003 May $1 ; 38(2): 141-9$.

[103] Chevrier S. Gérer des équipes internationales: tirer parti de la rencontre des cultures dans les organisations. Presses de l'Université Laval; 2012.

[104] Chanlat JF, Dameron S, Dupuis JP, De Freitas ME, Ozbilgin M. Management et Diversité: lignes de tension et perspectives. Management international. 2013; 17(hors série).

[105] Segal JP. Les bonnes surprises du management interculturel: 
le redressement spectaculaire d'une entreprise de transport public de Nouvelle-Calédonie. InAnnales des Mines-Gérer et comprendre 2013 (No. 4, pp. 61-72). ESKA.

[106] Rémi B, Chevrier S. Le management interculturel: accompagner l'internationalisation des entreprises. 2013.

[107] Frenkel M. The politics of translation: How state-level political relations affect the cross-national travel of management ideas. Organization. 2005 Mar; 12(2):275-301.

[108] Frenkel M. The Americanization of the Antimanagerialist Alternative in Israel: How Foreign Experts Retheorized and Disarmed Workers' Participation in Management, 1950-1970. International Studies of Management \& Organization. 2008 Dec 1; 38(4):17-37.

[109] Drucker PF. The future of industrial man. Routledge; 2017 Jul 12.

[110] Drucker PF. Concept of the Corporation. Transaction Publishers; 1993.

[111] Schwartz M. Drucker's communitarian vision and its implications for business ethics. Business Ethics: A European Review. 2004 Oct;13 (4):288-301.

[112] Chevrier S. La gestion prend-elle les cultures au sérieux?. Le débat. 2015(3):147-59.

[113] Chevrier S. Les pratiques de management interculturel. Que sais-je?. 2013;3:99-120.

[114] Chanlat JF, Dameron S, Dupuis JP, De Freitas ME, Ozbilgin M. Management et Diversité: lignes de tension et perspectives. Management international. 2013;17(hors série).

[115] d'Iribarne P. The usefulness of an ethnographic approach to the international comparison of organizations. International Studies of Management \& Organization. 1996 Dec $1 ; 26(4): 30-47$.

[116] Oiry E, d'IRIBARNE A. La notion de compétence: continuités et changements par rapport à la notion de qualification. Sociologie du travail. 2001 Jan 1;43(1):49-66.

[117] Crozier M. The bureaucratic phenomenon. Transaction Publishers; 2009 Dec 1.

[118] Romano S, Lazar M, Canonica M. L'Italia disunita. Milano: Longanesi; 2011 Mar 15.

[119] Guénette AM, Mutabazi S, Van Overbeck Ottino S, Pierre P. Management interculturel, altérité et identités. L'Harmattan; 2014 Nov 15.

[120] Cazorzi, C., \& Montenero, V.. Bien communiquer, travailler et négocier avec vos interlocuteurs italiens Paris: AFNOR. 2012 